\title{
OBITUARY \\ Obituary for Professor John Stuart Garrow 19 April 1929 - 22 June 2016
}

International Journal of Obesity (2016) 40, 1607; doi:10.1038/ ijo.2016.144

John Garrow was a pioneer in obesity research and an inventor of some of the critical instruments used in clinical medicine and scientific laboratories. He was born in Dundee, Scotland, educated in London, and studied medicine at the University of St Andrew's in Dundee. After serving in the Second World War, he assumed a junior hospital post in the newly formed Medical School in the British Colony of Jamaica where he observed the problem of severe childhood malnutrition. These very sick children often died if they were fed a full diet abruptly. He joined Dr John Waterlow, an expert on fatty liver disease in infants, in the Tropical Metabolism Research Unit funded by the UK's Medical Research Council (MRC). While in Jamaica, Garrow developed a chromatographic system for distinguishing sickle cell haemoglobin and invented the first windowless gas flow counter to measure soft beta emitters (C 14 and S35) at exceptionally low levels of radioactivity in small biopsies taken from the malnourished babies. He used the beta counter to determine whether protein deficiency with subsequent alterations in protein metabolism and body composition underlay the major cardiovascular, hepatic and electrolyte problems of the severely malnourished infants. After animal and cadaver studies in conjunction with his long-standing colleague, David Halliday, he began a series of classic in vivo studies on the body composition and electrolyte changes in malnourished children, and developed experimental feeding regimens which led to a fall in death rates. Garrow obtained $\mathrm{NIH}$ funding and major input from the US company, Packard, to build a $4 \pi$ cylindrical liquid scintillation counter which he used to measure potassium ${ }^{40}$ content as a method of assessing lean body mass in infants weighing 1-10 kg. In addition to these inventions, he developed the zero muddler sphygmomanometer that reduced errors in blood pressure readings due to rounding of systolic and diastolic blood pressures with previous instruments.

He then served in the RAF Institute for Aviation Medicine in Farnborough, where he invented a steam-operated centrifuge for rapidly spinning down small blood samples at high altitude. This was used by John Waterlow on his Andes expedition to study medical adaptation to high altitudes. Garrow moved to the MRC Clinical Research Centre in Northwick Park Hospital, Harrow, UK, and began working on the problems of obesity. In order to study energy balance, he built a combined indirect and direct calorimeter for every day movement and meal responses, the first since Atwater's calorimeter in the 1880s. He also built a partially water-filled body plethysmograph to measure body composition. These studies culminated in his book, 'Energy Balance and Obesity in Man.' During this time he rose to be head of the Nutrition Research Unit at the MRC Clinical Research Centre, Harrow and experimented with techniques such as jaw wiring and a fixed tight waist band to help obese people control eating and reduce body weight. He became increasingly concerned with the fraudulent claims of medical and herbal quacks, which he countered with a series of highly critical commentaries and expert witness reports for legal cases. He wrote the book, 'Treat Obesity Seriously' in order to educate the public about the medical and psychological contributions to obesity.

Moving further into the field of nutrition, he and Phillip James began editing the 'Textbook of Human Nutrition', previously edited by Passmore and Truswell, and he took over as Editor of the European Journal of Clinical Nutrition for a decade. Upon retirement, he helped to found Healthwatch, a charity concerned to promote evidence-based medicine and to expose fraudulent claims.

During his long career he had many professional achievements including: Professor of Human Nutrition, University of London, Honorary consultant physician St Bartholomew's Hospital, St Mark's Hospital, Royal London Hospital and Northwick Park Hospital. He also was the head of Nutrition Research Unit at the MRC Clinical Research Centre, Harrow, and member of Department of Health Committee on Medical Aspects of Food Policy; Chair of the Joint Advisory Committee on Nutrition Education and the Chair of Association for the Study of Obesity.

No tribute would be complete without mentioning his wife Kate and his family. He first met Kate on the medical staff in Jamaica when he was lurid blue from injecting himself with Evans Blue as he attempted to measure albumin turnover. They had four children, and in his retirement they moved from London to Yorkshire to be close to his general practitioner daughter and his son, an Anglican clergyman. John Garrow was a pioneer and an inventor, and not only contributed enormously to our understanding of obesity, but as a physiologist and elegant and sophisticated writer, he constantly emphasised the importance of the highest standards in science and public service.

WPT James

London School of Hygiene and Tropical Medicine, London, UK E-mail: jeanhjames@aol.com 